O R I G I N A L A R T I C L E

\title{
Universal Precautions against HIV and other Blood-Borne Pathogens - Knowledge, Attitude and Compliance among health professionals in Obstetrics and Gynecology
}

Bhalinder Dhaliwal, Pradip Kumar Saha, Poonam Goel, Anju Huria

Dept of Obs/Gyn Government Medical College \& Hospital, Sector 32, Chandigarh, India

\begin{abstract}
Aim: To assess the knowledge and compliance with universal precautions (UP) for the labour wards, delivery and operating rooms by Doctors, Nurses and Technicians

Methods: Study Design: The study was conducted in two teaching hospitals in Chandigarh. Health Care Worker working in the Obstetrics and Gynecology department were surveyed by a pretested detailed confidential questionnaire to asses the knowledge and compliance with UP. And also if they are not using what could be the reason for noncompliance.

Results: Hundred percent of doctor had knowledge about UP where as it was $80 \%$ in staff nurse and $82 \%$ in OT technician. Around Thirty eight percent of the respondent always used double gloves, $18.4 \%$ protective eyewear, 34.5\% protective outer clothing (plastic inner covering wear inside gown) and 10.5\% used Gumshoes (protective foot wear). Around six percent respondent never used double gloves, 64\% protective eyes wear, and $13.3 \%$ protective outer clothing and $61.2 \%$ never used Gumshoes. Reasons for noncompliance with UP as elicited by this study included time constraints (53\%), inconvenience (19.3\%), non-availability of protective barrier (88\%) and presumption that patient was not infected (51.6\%).

Conclusions: Results from this study reveal that there is a fair level of knowledge about universal precaution among the Health Care Worker (HCW). But Compliance with universal precautions by participant is poor. So, Training programs and other strategy should be put in place to promote the appropriate use universal precaution among Health care professional.
\end{abstract}

Key words: Knowledge, Attitude, Compliance of Universal Precautions

\section{Introduction}

Owing to the nature of their work $\mathrm{HCW}$ in the area of Obstetrics \& Gynecology are faced daily with potential exposure to patients' body fluids (including blood, urine and amniotic fluid). Exposure may also result in the form of percutaneous injury from contaminated needles that abound in labour and delivery rooms and operation theatres. As a result, $\mathrm{HCW}$ are at an increased risk of exposure to blood-borne pathogens, including
Hepatitis B virus (HBV), Hepatitis C virus (HCV) and Human Immunodeficiency virus (HIV). Estimates of infectivity of HCW exposed to HBV range from $2-40 \%$, with $\mathrm{HCV}$ is up to $10 \%$, and the estimated risk of obtaining HIV from a percutaneous exposure in health care setting is approximately $0.3 \%{ }^{1}$.

The Center for Disease Control (CDC Atlanta, USA) has published specific universal precautions guidelines

Correspondence

Dr Pradip Kumar Saha, MD,MAMS,FIMSA

Assistant Prof Dept of Obs/Gyn

Government Medical College \& Hospital,

Sector 32, Chandigarh, India

Pin-160030

Phone : 91-9646121583

Email : pradiplekha@yahoo.co.in 
that address the issue of prevention of occupational exposure to blood-borne pathogens ${ }^{2}$. This approach emphasizes the consistent use of blood and body fluid precautions for all patients and these recommendations introduce the concept that "all patients should be assumed to be infected with HIV and other bloodborne pathogens.

Due to the risk of acquiring life-threatening bloodborne pathogens, it would be reasonable to expect that the $\mathrm{HCW}$ working in the potentially hazardous environment of labour and delivery rooms would adhere to strict precautions against such exposures. However, recent studies have shown that compliance with these precautions in the high-risk setting of emergency wards, operation theatres and critical care units is less than optimal ${ }^{3-5}$. Hence, compliance with universal precautions is an important issue and it is prudent to determine the reasons for failure of compliance with these precautions.

\section{Objectives}

To assess the knowledge, awareness and compliance of the UP necessary to be followed in the delivery and operating rooms by the $\mathrm{HCW}$ in the field of Obstetrics and Gynecology.

\section{Method}

It was a questionnaire-based study in which $\mathrm{HCW}$ (Doctors, nurses and technicians) from the Departments of Obstetrics \& Gynecology in Government Medical College and Hospital, sector 32 Chandigarh and Postgraduate Institute of Medical Education and
Research, Chandigarh were required to fill up confidential pretested proformas regarding knowledge, awareness and practice of UP. Questionnaire also included reason for noncompliance. Only HCW having direct patient contact were included. Total 236 proformas were distributed. Nine subject did not return there proforma and ten proforma were incomplete. On the basis of information, collected data was analyzed in 217 respondents.

\section{Results}

Total 217 respondents (table 1) were finally included in this study of which 92 were doctor, 89 staff nurse and 36 were technician. Hundred percent of doctors had knowledge about UP where as $80 \%$ of staff nurse and $82 \%$ of OT technician had knowledge.

\section{Table 1. Participants in the study}

\begin{tabular}{lc}
\hline \multicolumn{2}{l}{ Total Number of Respondents } \\
$\begin{array}{l}\text { Data analyzed in } \\
\text { (i) } \quad \text { Doctors }\end{array}$ \\
- 236 \\
- Consultants & \\
- Senior Residents & 25 \\
- Junior Residents & 29 \\
- Research Assistants & 36 \\
(ii) Nurses & 02 \\
(iii) O.T. Technicians & 89 \\
\end{tabular}

Table 2. Frequency of use of following measures by Health Care Worker

\begin{tabular}{|c|c|c|c|c|c|c|c|c|}
\hline \multirow[t]{2}{*}{ S.N } & & \multicolumn{2}{|c|}{ Doctors } & \multicolumn{2}{|c|}{ Nurses } & \multicolumn{2}{|c|}{ O.T.Technicians } & \multirow[t]{2}{*}{ Total (\%) } \\
\hline & & (92) & $\%$ & (89) & $\%$ & $(36)$ & /o & \\
\hline \multirow[t]{4}{*}{1} & Double Gloves & No. & \%age & No. & \%age & No. & \%age & \\
\hline & Always & 41 & $44.6 \%$ & 26 & $29.2 \%$ & 15 & $41.6 \%$ & $82 \quad(37.7 \%)$ \\
\hline & Often & 39 & $42.4 \%$ & 61 & $68.5 \%$ & 21 & $58.3 \%$ & $121(55.7 \%)$ \\
\hline & Never & 12 & $13 \%$ & 02 & $2.2 \%$ & None & $0 \%$ & $14 \quad(6.45 \%)$ \\
\hline \multirow[t]{4}{*}{2.} & $\begin{array}{l}\text { Protective Eye } \\
\text { Wear }\end{array}$ & & & & & & & \\
\hline & Always & 17 & $18.5 \%$ & 19 & $21.3 \%$ & 04 & $11.1 \%$ & $40 \quad(18.4 \%)$ \\
\hline & Often & 24 & $26.1 \%$ & 09 & $10.1 \%$ & 05 & $13.9 \%$ & $38 \quad(17.5 \%)$ \\
\hline & Never & 51 & $55.4 \%$ & 61 & $68.5 \%$ & 27 & $75 \%$ & $139(64 \%)$ \\
\hline \multirow[t]{4}{*}{3.} & $\begin{array}{l}\text { Protective } \\
\text { Outer Clothing }\end{array}$ & & & & & & & \\
\hline & Always & 25 & $27.2 \%$ & 35 & $39.3 \%$ & 15 & $41.7 \%$ & $75 \quad(34.5 \%)$ \\
\hline & Often & 44 & $47.8 \%$ & 50 & $56.2 \%$ & 19 & $52.8 \%$ & $113(52 \%)$ \\
\hline & Never & 23 & $25.0 \%$ & 04 & $4.5 \%$ & 02 & $5.5 \%$ & $29 \quad(13.3 \%)$ \\
\hline \multirow[t]{4}{*}{4.} & Gum shoes & & & & & & & \\
\hline & Always & 5 & $5.4 \%$ & 14 & $15.7 \%$ & 04 & $11.1 \%$ & $23(10.5 \%)$ \\
\hline & Often & 24 & $26.1 \%$ & 36 & $40.4 \%$ & 01 & $2.7 \%$ & $61(28.1 \%)$ \\
\hline & Never & 63 & $68.5 \%$ & 39 & $43.8 \%$ & 31 & $86.1 \%$ & $133(61.2 \%)$ \\
\hline
\end{tabular}


Table 3. Reason for noncompliance

\begin{tabular}{|c|c|c|c|c|c|c|c|c|}
\hline S.N & & \multicolumn{2}{|c|}{ Doctors } & \multicolumn{2}{|c|}{ Nurses } & \multicolumn{2}{|c|}{ Technicians } & Total (\%) \\
\hline \multirow[t]{3}{*}{1} & Time Constraints & & & & & & & \\
\hline & Yes & 38 & $41.3 \%$ & 66 & $74.2 \%$ & 13 & $36.1 \%$ & $117(53 . \%)$ \\
\hline & No & 54 & $58.7 \%$ & 23 & $25.8 \%$ & 23 & $63.9 \%$ & $100(47 \%)$ \\
\hline \multirow[t]{3}{*}{2.} & Inconvenience & & & & & & & \\
\hline & Yes & 28 & $30.4 \%$ & 06 & $6.7 \%$ & 08 & $22.2 \%$ & $42 \quad(19.3 \%)$ \\
\hline & No & 64 & $69.5 \%$ & 83 & $93.3 \%$ & 28 & $77.8 \%$ & $175(80.6 \%)$ \\
\hline \multirow[t]{3}{*}{3.} & $\begin{array}{l}\text { Non-Availability of } \\
\text { Equipment }\end{array}$ & & & & & & & \\
\hline & Yes & 78 & $84.8 \%$ & 79 & $88.8 \%$ & 34 & $94.4 \%$ & $191(88 \%)$ \\
\hline & No & 14 & $15.2 \%$ & 10 & $11.2 \%$ & 02 & $5.6 \%$ & $26(12 \%)$ \\
\hline \multirow[t]{3}{*}{4.} & $\begin{array}{l}\text { Presumption that } \\
\text { patient is not infected } \\
\text { with } \mathrm{HIV} / \mathrm{HbsAg}\end{array}$ & & & & & & & \\
\hline & Yes & 27 & $29.3 \%$ & 73 & $82.0 \%$ & 12 & $33.3 \%$ & $112(51.6 \%)$ \\
\hline & No & 65 & $70.6 \%$ & 16 & $18.0 \%$ & 24 & $66.7 \%$ & $105(48.4 \%)$ \\
\hline
\end{tabular}

Around Thirty eight percent of the respondent always used double gloves, $18.4 \%$ protective eyewear, $34.5 \%$ protective outer clothing (plastic inner covering wear inside gown) and 10.5\% used Gumshoes (protective foot wear). Around six percent respondent never used double gloves, $64 \%$ respondent never used protective eye wear, $13.3 \%$ respondent never used protective outer clothing and $61.2 \%$ respondent never used Gum shoes (table 2).

When we compared always use of double gloves among different category of health worker, compliance were more among doctors $(44.6 \%)$, followed by technician $(41.6 \%)$ and nurses $(29.2 \%)$.

Similarly when we compared always use of protective eyewear compliances were similar among doctors $(18.5 \%)$ and nurses $(21.3 \%)$ but less among technicians $(11.1 \%)$

However compliances of protective outer clothing was maximum among technicians $(41.7 \%)$ followed by nurses $(39.3 \%)$ then doctors $(27.2 \%)$

Compliance to gum shoes maximum among staff nurse $(15.7 \%)$ followed by technician $(11.1 \%)$ and then doctors $(5.4 \%)$.

In this study also revealed that $6.4 \%$ respondent never used double gloves, $64 \%$ protective eye wear, $13.3 \%$ protective outer clothing and $61.2 \%$ gum shoes.

Study also revealed the reason for noncompliance with UP.

Rationale for lack of compliance with universal precautions elicited by the questionnaire included time constraints $(53 \%)$, inconvenience $(19.3 \%)$, non- availability of equipments ( $88 \%$ ) and presumption that patient was not infected (51.6\%) (Table 3).

When it was asked whether they want to use all protective measure if patient is found to be HIV or HbSAg positive, all of them expressed there willingness to adherent to universal precaution.

\section{Discussions}

Universal precaution guidelines were developed to prevent the transmission of infections borne in the blood and other body fluids to health care workers. Since their Introduction, they have become standard practice in all medical facilities.

However it cannot represent health care provider working in other specialty. Study showed $37.7 \%$ of the respondent always used double gloves and 55.7\% often used this however $6.4 \%$ never used this.

This study also revealed compliance with protective eye wears always used by $18.4 \%$ respondent, often in $17.5 \%$ and never by $64 \%$.

It also showed that $34.5 \%$ of respondent always used protective outer clothing, $52 \%$ often and $13.3 \%$ never used it.

When it comes to use of Gum shoes $10.5 \%$ respondent always used it, $28.1 \%$ often and $61.2 \%$ never used it.

Similar type of study from Nigeria assessing the observance of universal precautions by Health care workers showed that two-thirds of respondents $(63.8 \%)$ always used personal protective equipment, and more than half of all respondents $(56.5 \%)$ had never worn goggles during deliveries and at surgeries ${ }^{4}$. In our 
study also $64 \%$ respondent never used protective eye wear.

Another study to assess self-reported levels of compliance with universal precautions among hospitalbased health care workers showed extremely high for certain activities (e.g., glove use, $97 \%$; to low for others (e.g., wearing protective outer clothing, 62\%; wearing eye protection, $63 \%)^{6}$.

Other study in polish article was to estimate how often surgeons use surgical gowns, masks, gloves and eyewear in the context of occupational exposure to HIV. Here it was noted that surgeons infrequently used preventive strategies. Regular use of double gloving was reported only by $8.5 \%$ of respondents, eye protection by $23 \%$. About three-quarters of surgeons reported they always used masks and gowns, $86 \%$ single gloves ${ }^{7}$.

In our study rationale for lack of compliance with universal precautions elicited by the questionnaire were, inconvenience, non-availability of equipments and presumption that patient was not infected (Table2). These results were similar to other previous study where the reasons for not using protective attire were i.e, supplies not available, insufficient time, discomfort, gloves do not fit, too much trouble to get ${ }^{8,9}$.

In our study we did not include recapping of needle and hand washing in proforma.

Our study reveals that compliance with Universal Precaution is poor. In India prevalence of HIV and HbSAg are quiet high ${ }^{10}$.

\section{Conclusion}

To improve the situation, efforts will need to be done to motivate the health care worker to adopt preventive measures through adequate education system. Improving the comfort of barrier precautions and making them available may also increase the compliance with protection against blood born infection.

\section{References}

1. Lymer UB, Richt B, Isaksson B. Blood exposure- Factors promoting health care workers' compliance with guidelines in connection with risk. J Clin Nurs 2004 ; 13: 547-554.

2. Department of Health and human services, Centre for disease control. Universal Precautions for Prevention of Transmission of HIV and Other Blood borne Infections 1996 http://www.cdc. gov/ncidod/dhqp/bp_universal_precautions.html

3. Michalson A, Delclos GL, Felknor SA, Davidson AL, Johnson PC, Vesley D, Murphy LR, Kelen GD, Gershon RR. Compliance with universal precautions among physicians. J Occup Environ Med 1997; 39: 130-137.

4. Sadoh WE, Fawole AO, Sadoh AE, Oladimeji AO, Sotiloye OS. Practice of universal precautions among healthcare workers. J Natl Med Assoc 2006; 98: 722-726.

5. Stein AD, Makrawo TP, Ahmad MF. A survey of doctors' and nurses' knowledge, attitudes and compliance with infection control guidelines in Birmingham teaching hospitals. J Hosp Infect 2003; 54: 68-73.

6. Gershon RR, Vlahov D, Felknor SA, Vesley D, Johnson PC, Delclos GL, Murphy LR. Compliance with universal precautions among health care workers at three regional hospitals. Am J Infect Control 1995: 23: 225-236.

7. Ganczak M, Bialecki P, Boron-Kaczmarska A, Szych Z; Use of preventive strategies by surgeons and HIV exposure [Article in Polish] Wiad Lek 2004; 57:221-228.

8. Nelsing S, Nielsen TL, Nielsen JO. Noncompliance with universal precautions and the associated risk of mucocutaneous blood exposure among Danish physicians. Infect Control Hosp Epidemiol 1997; 18: 692-698.

9. Picheansathian W. Compliance with universal precautions by emergency room nurses at Maharaj Nakorn Chiang Mai Hospital. J Med Assoc Thai 1995; 78 Supple 2:S118-122.

10. NACO (2007) 'HIV sentinel surveillance and HIV estimation in India 2007: A technical brief'. 